\title{
一側性声帯麻摩に対する経皮的シリコン注入術
}

\author{
飯田順, 中島 久美, 堤 康一 朗 \\ 岩武博也，南定，竹山勇
}

\section{Transcutaneous Silicone Injection Unilateral Vocal Cord Paralysis}

Jun Iida, M.D., Kumi Nakajima, M.D., Kouichirou Tsutsumi, M.D., Hiroya Iwatake, M.D., Sadamu Minami, M.D., and Isamu Takeyama, M.D.

*Department of Otolaryngology, St. Marianna University School of Medicine, Kawasaki

The authors report the results of transcutaneous silicone injection in 8 cases of unilateral vocal cord paralysis who complained of hoarseness. In order to medialize the vocal cord, injection was done to outside of the vocal cord through the cricothyroid space under local anesthesia. This procedure was successful in improvement of phonatory function in most cases. Transcutaneous silicone injection is recommended in unilateral vocal paralysis case, especially who are unable to undergo general anesthesia.

Key words：一側性声帯麻疸，経皮的シリコン注入術

\section{I . 緒 言}

一側性声帯麻舫の際に生じる嗄声の改善を目 的とした手術には，種々の方法があるが，それ らの中でもシリコンを声帯の側方に注入する方 法は，手技の容易さ，注入材料としての安定度 の点で優れ, 幅広く用いられている。シリコン の注入法としては，従来行われてきた経口的に 注入する方法に比較し，近年，外来にて簡易に 実施できる経皮的注入法が報告されてい $3^{1 \sim 4)}$ 。私どもは甲状軟骨の下方より声帯の側方 にシリコンを注入する方法を用いており，手術 前後の音声機能検査成績とともに, 本手術法に ついての考察を加え報告する。

\section{II. 方 法}

注入に用いたシリコンは固化型で, シリコン

聖マリアンナ医科大学耳鼻咽喉科

別刷請求：干213 神奈川県川崎市宮前区菅生2-16-1 聖マリアンナ医科大学耳鼻咽喉科 飯田 順

投稿受付：1990年 8 月 15 日
の混合比は, Phycon 6500 と Phycon 6500 additive がそれぞれ $1: 1$ または $1: 2$ とし，カタリ ストを $21 \mathrm{G}$ 針にて 4 〜 滴加えた。注入には口 ック付 $2 \mathrm{ml}$ の注射器と $18 \mathrm{G}$ の針を用いた。

麻酔前投薬として, 硫酸アトロピンを投与し, $4 \%$ \%シロカインにて鼻咽喉頭を表面麻酔した 後, 仰臥位とし肩枕にて頸部を軽度伸展した。 甲状軟骨を触診し, 上甲状切痕と甲状軟骨正中 部下縁を結んだ線の中央の高さより外側に, 甲 状軟骨下縁と平行にピオクタニン等の色素で線 を引き, 声帯上縁の目安とし,これょりもやや 下方に注入されるように，皮膚からの距離を計 測し，注入時の参考となるようにした。

前頸部皮膚に浸潤麻酔を行い, 大久保ら ${ }^{21}$ の 方法に準じて, 正中より $5 \mathrm{~mm}$ 外側の輪状甲状 膜より, $18 \mathrm{G}$ 針の針穴が外側に位置するように しながら上方に向けて刺入し，調合したシリコ ンが声带のレベルに達するように注入した。こ の際, 経鼻的に挿入したファイバースコープに よる声帯所見の変化をテレビモニターにて観察 し, また, 発声させて音声の改善を確認しなが ら, 適量のシリコンを注入した。注入前後に音 
声機能検査，音声録音を行って，注入効果を評 価した。

図 1 は実際にシリコンの注入を行っていると ころで，輪状甲状膜を穿刺し，声帯所見を経鼻 的に插入したファイバースコープで確認してい る。

\section{III. 結 果}

今回，経皮的にシリコンを注入したのは 8 例 で，男性 5 名女性 3 名であり，年齢は 55〜 72歳 (平均64.9歳)であった。声帯麻疸の原因となっ た疾患は，悪性腫瘍，またはその手術によるも のが 6 例と多く，他は大動脈瘤，またはその手 術によるものであった。患側は全例左側で，全 例左声帯膜様部に弓状萎縮を認め, 声帯位は副 正中位が多く, 声帯麻痺発症から注入までの期 間は 5 ３1力月（平均13.6力月）であった。シ リコン注入量は $0.5 \sim 2.0 \mathrm{ml}$ (平均 $1.2 \mathrm{ml}$ ) であ った。表 1 にこれらの症例の内訳を示す。また，

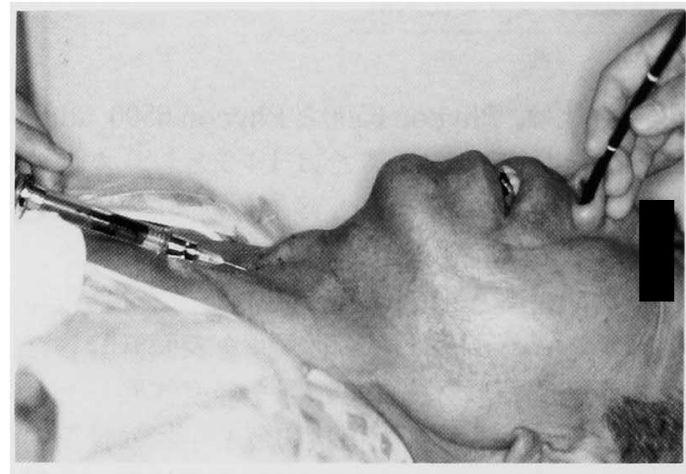

図 1 輪状甲状膜より声帯の外側に向けてシリコン を注入し，声帯所見をファイバースコープに て確認している
図 2A，B に代表例の手術前後の発声時声帯所 見を示す。

手術後の所見では，注入中に針先が深く入つ た結果，声帯のみならず仮声帯の膨隆も認めら れたが，音声はほぼ満足できるものであった。 図 3 に最長持続発声時間について，比較した注 入前後の結果を示す。注入前はすべて 6 秒以下 であったが，注入後はほとんどの症例が改善を 認めた。

また，最長持続発声時の平均呼気流率につい て，計測できなかった 2 例を除いた 6 例につい
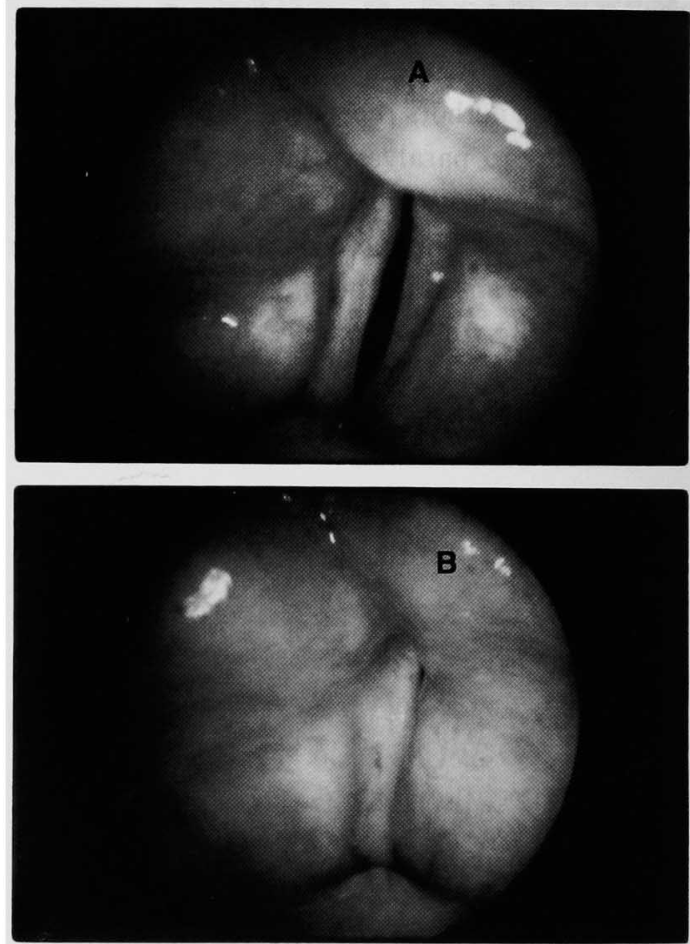

図 2 声帯硬性内視鏡所見 (A：注入前, B : 注入 後)

表 1 症 例

\begin{tabular}{|c|c|c|c|c|c|c|c|c|}
\hline 症例 & 性 & 年齢 & 因 & 患側 & 萎縮 & 声帯位 & 注入までの期間 & 注入量 \\
\hline 1 & 男 & 62 & 綐隔悪性腫瘍 & 左 & 有 & 副正中位 & 6 力月 & $1.0 \mathrm{ml}$ \\
\hline 2 & 男 & 57 & 胸部大動脈瘤手術 & 左 & 有 & 副正中位 & 24力月 & $0.8 \mathrm{ml}$ \\
\hline 3 & 男 & 59 & 肺癌手術 & 左 & 有 & 中間位 & 8 力月 & $2.0 \mathrm{ml}$ \\
\hline 4 & 女 & 72 & 胸部大動脈瘤 & 左 & 有 & 副正中位 & 31力月 & $1.0 \mathrm{ml}$ \\
\hline 5 & 女 & 60 & 胸腺癌 & 左 & 有 & 副正中位 & 8 力月 & $0.5 \mathrm{ml}$ \\
\hline 6 & 男 & 72 & 食道癌 & 左 & 有 & 副正中位 & 5 力月 & $1.3 \mathrm{ml}$ \\
\hline 7 & 女 & 69 & 綐隔癌 & 左 & 有 & 中間位 & 12力月 & $2.0 \mathrm{ml}$ \\
\hline 8 & 男 & 68 & 肺癌手術 & 左 & 有 & 正中位 & 15カ月 & $1.2 \mathrm{ml}$ \\
\hline
\end{tabular}




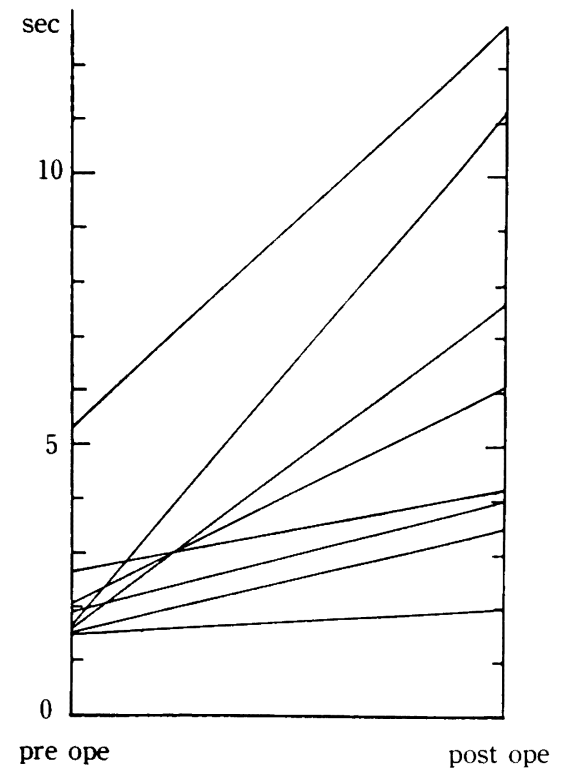

図 3 注入前後の最長持続発声時間

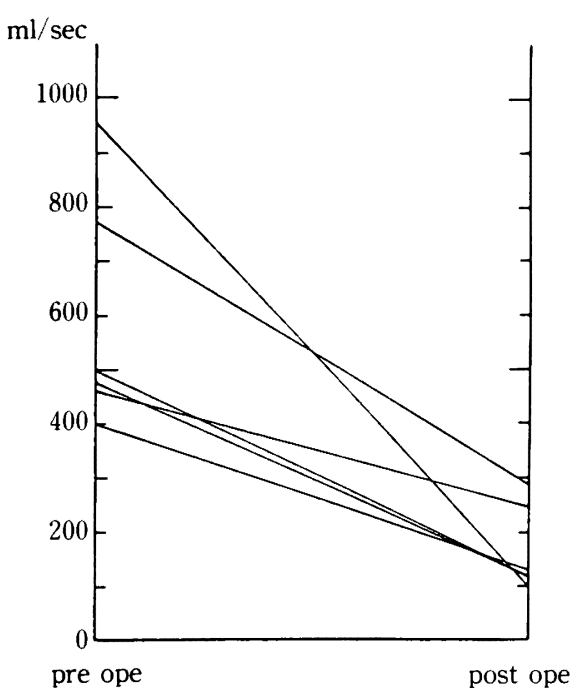

図4 注入前後の平均呼気流率

ての結果を図 4 に示す。いずれも手術後は正常 値に近い値を示した。術前後の最長持続発声時 間に著明な変化を認めなかった 1 例は音声の改 善が得られなかったが，他の症例は自他覚的に も音声の改善を示した。

\section{IV. 考察}

これまでに，声帯に対し経皮的に注射を行い， 声帯麻痺の際に生じる嗄声を改善させる方法と しては，針を刺入する部位の違いから大別する と三種類あり，これらは声帯の高さで甲状軟骨 を直接穿刺する方法 1.3$)$, 甲状軟骨の上方から声 帯を狙う方法1,4)，甲状軟骨の下方から声帯を狙 う方法2゙である。

甲状軟骨を穿刺し注入する場合，軟骨の化骨 があると通常の針では刺入できず，骨髄穿刺針 等の特殊な器具を用いる工夫到が必要となる。 一方，甲状軟骨の上方または下方から声帯に向 けて注入を行う方法は，針の刺入は容易である が, 針先の位置の確認が難しいという点が最大 の欠点である。しかし，これらの治療成績2 4) を 比較すると，大久保らの成績は全例比較的良好 な最長持続発声時間の改善を認めているが, そ の症例数は 4 例と少ない。また他の報告3,4) で も，自験例と同様に術後の最長持続発声時間の 延長がわずかな程度に留まるものが数例みら れ, 成績に著しい差はないようであり, 術者の 好みによって選択すればよいようにも思われ る。

注入時の声帯の観察法としては，間接喉頭鏡 を用いる報告" ${ }^{1)}$ 経鼻的に插入したファイバー スコープを用いる報告 2 (4) とがある。穿刺部位が いずれであっても，仰臥位の方が座位よりも注 入しやすいと考えられることから，間接喉頭鏡 は使いにくく，また，注入を行いながら，同時 にモニターテレビにて所見を確認できる点でも ファイバースコープを使用する方が優れている と思われた。

注入材料としては, 固化型の Phycon ${ }^{2,4)}$ と液 状のエリコンャング1)の二種類が使用されてい るが，注入部位からの漏れがより少なく，この ため効果の安定性が良いことから Phyconの方 が良いと考えた。Phyconの混合比に関しては， 自験例では $1: 1$ と $1: 2$ を試みたが, 粘度の高 い $1: 1$ の方が注入後の変形がより少ないと考 えられ, 注入の際に抵抗が強く時間がかかると いうこともなかったので，やや粘性の高い方が 良いと思われた。

次に大久保ら ${ }^{2)}$ は，経皮的アプローチの場合 
は, 経口的アプローチに比較した場合, 注入部 位からの漏札がないこと, 喉頭展開が難しい症 例でも可能なこと, 発声が自然であること, 生 体に対する侵襲が少ないことなどの利点をあげ ている。私どもはこのなかでも, 局所麻酔下に 外来で行うことができるので，侵襲が少なく， 全身麻酔ができなかったり, 患者が全麻を好ま ない場合でも可能であるという点が，最大の利 点であると考えた。

また，これら以外に今回の経験から甲状軟骨 の下方から刺入する方法は, 次に述べるうな 長短があると考えられた。すなわち, 利点とし てはシリコンさえあ机ば，直達鏡下や間接鏡下 の注入と異なり, 特殊な針は必要としないとい うこと。欠点としては経口的アフローチに比し， 喉頭ファイバーでの声带の確認が難しい場合が あること, 患者が嶼下すると喉頭が動いて針先 の位置がずれ, 適切な部位への注入が難しくな ること, 喉頭ファイバーを行う都合上, 術者が 2 名必要であること等であった。

したがって嗄声が比較的軽度で, 発声時の声 門間隙が小さく，注入部位や注入量に微妙な技 術を要するような症例には向かないと考えら机 た。これらの事情は, 甲状軟骨の上方からのア プローチについても共通していると考えられ た。

また, 今回の結果からみて, 経皮的アプロー チはまだ手技に慣れていないためか, 経口的ア プローチに比し,やや音声の改善率は悪いよう にも思わ扎たが,本法は外来にて局所麻酔下で，
短時間で実施でき，患者への侵襲が少ないこと から, 進ら ${ }^{3)}$ が指摘しているように，すでに麻痺 の原因となった疾患に対して手術が行われてい るような症例では, 患者が頻回の入院や大袈裟 な手術を好まない場合があり, 術後性声帯麻痺 症例には良い適応と考えられた。

さらに, 特に声帯麻瘏の原因が悪性腫瘍であ る場合は, 予後が不良で全身麻酔が不可能であ ることもあり，まず経皮的な方法を試みる価値 があると考えられた。

\section{V.まとめ}

一側性声帯麻盘 8 症例に対し, 甲状軟骨下方 から経皮的にシリコンを注入した。

この方法は, 局所麻酔下に比較的簡易に実施 できる点で優れていると考えられた。

本論文の要旨は, 第91回日本耳鼻咽喉科学会総会 において発表した。

\section{文献}

1) 佐藤武男, 山本邦之, 内海重光 - 他：耳鼻咽喉 科における甲状腺癌の実態と治療。耳鼻臨, 64 ： 514-522, 1971.

2 ) 大久保洋, 平野 実, 吉田哲二-他: 経皮的 リコン注入の経験。耳鼻, $24: 879-881,1984$.

3 ) 進武幹, 松尾浩一, 渡辺宏・他: 反回神経 麻瘦に対する経皮的声带内注入法. 日気食会報, $36: 450-454,1985$.

4 ）北原 哲, 小倉雅実, 坂田淳一・他：片側声带 麻痺に対する経皮的シリコン注入術. 日気食会 報, $39 ： 471-475,1988$. 